As-Syifaa Jurnal Farmasi Desember 2020;12(2):91-98.

ISSN : 2502-9444 (electronic); 2085-4714 (printed)

Journal Homepage : http://jurnal.farmasi.umi.ac.id/index.php/as-syifaa

\title{
EVALUASI PENGGUNAAN ANTIBIOTIK DENGAN METODE ATC/DDD DAN DU 90\% DI PUSKESMAS AUR DURI KOTA JAMBI PERIODE 2016-2018
}

\author{
Yuni Andriani, Aris Sahat Martua, Medi Andriani \\ Program Studi Farmasi, STIKES Harapan Ibu Jambi \\ Email: arissahatmartua@gmail.com
}

\begin{abstract}
Introduction: Since 23 years ago, WHO transferred ATC (Chemical Therapeutic Chemical) and DDD (Defined Daily Dose) as a global standard for the study of drug use, one of which is antibiotics. Drug Use Method 90\% (DU 90\%) method that shows the grouping of drugs that fall into the $90 \%$ category of use that is often used in conjunction with an analysis of the use of ATC / DDD drugs. Research Objectives: determine the use of antibiotics in Aur Duri Health Center in Jambi City based on the ATC / DDD method and DU 90\% for the 2016-2018 period. Research Methods: Retrospective data collection using ATC / DDD and DU 90\% methods. Results: Of the four types of antibiotics, the highest DDD value was obtained at Aur Duri Health Center for the period of 2016-2018, namely amoxicillin antibiotics. Antibiotics that entered the DU 90\% segment at Aur Duri Health Center based on data for the 2016-2018 period were amoxicillin, ciprofloxacin and tetracycline. The most quantitative data using the ATC / DDD method is amoxicillin with the highest number of 39.39 DDD / $1000 \mathrm{KPRJ} /$ Year in Aur Duri Puskesmas in 2017.
\end{abstract}

Key words: Antibiotics, ATC / DDD, DU 90\% Segment.

\section{PENDAHULUAN}

Sejak 23 tahun yang lalu, WHO merekomendasikan ATC (Anatomical Therapeutic Chemical) dan DDD (Defined Daily Dose) sebagai standar global untuk studi penggunaan obat rasional, salah satunya

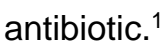

Penggunaan sistem ATC/DDD untuk pasien rawat jalan telah digunakan diberbagai negara seperti Jerman, India, Cina dan Belanda. Salah satu contoh di Belanda dilihat dari data DART (Deutsche AntibiotikaResistenzstrategie) menyatakan bahwa antibiotik tertinggi disana adalah antibiotik spektrum luas sedangkan di Indonesia belum ada data secara nasional. ${ }^{2}$ Penilaian terhadap obat yang masuk ke dalam segmen $90 \%$ diperlukan untuk menekankan segmen obat yang dikaji kaitannya dengan evaluasi pengendalian penggunaan dan perencanaan pengadaan obat. ${ }^{3}$
Berdasarkan hasil Penelitian sebelumnya antibiotik yang masuk segmen menggunakan DU 90\% di Puskemas mau pun di rumah sakit yang ada di Indonesia masih sangat sedikit. Beberapa diantaranya adalah Puskesmas di Surabaya dengan penggunaan 1006 DDD/1000 pasien (73\%). ${ }^{4}$ Berdasarkan penitian di bangsal penyakit dalam RSUD kerinci, sefatoksim merupakan antibiotik yang paling banyak digunakan. ${ }^{5}$

Antibiotik merupakan senyawa yang dihasilkan dari mikroba Monera, Protista, dan Fungi yang digunakan untuk membunuh atau menekan pertumbuhan bakteri. Kelompok obat yang digunakan untuk mengobati berbagai infeksi bakteri seperti radang tenggorokan, kulit, infeksi saluran kemih dan berbagai penyakit yang disebabkan oleh bakteri lainnya. Infeksi merupakan proses masuknya mikroorganisme dalam tubuh, kemudian berkembang biak dan menimbulkan penyakit. 
Sensitivitasnya tergantung dari jumlah kuman, tingkat keganasan, dan daya tahan tubuh. ${ }^{6}$ Kuantitas penggunaan antibiotik dilakukan penilaian yang bertujuan untuk perbaikan kebijakan atau penerapan program edukasi yang lebih tepat terkait kualitas penggunaan antibiotik. Penilaian dilakukan dengan menggunakan data Rekam Pemberian Antiobik (RPA), catatan medik pasien dan kondisi klinis pasien. Hal-hal yang dinilai antara lain ada tidaknya indikasi penggunaan antibiotik, pilihan jenis antibiotik dan sebagainya. ${ }^{7}$

\section{METODE PENELITIAN}

Penelitian ini merupakan penelitian bersifat deskriptif dengan cara pengambilan data secara retrospektif di Puskesmas Aur Duri

\section{HASIL DAN PEMBAHASAN}

ATC/DDD DAN DU $90 \%$

Tabel 1. Jumlah Pasien Berdasarkan Jenis Kelmain di Puskesmas Aur Duri Kota Jambi Periode 20162018

\begin{tabular}{cccc}
\hline Karakteristik Pasien & \multicolumn{3}{c}{ Puskesmas Aur Duri } \\
\hline Jenis Kelamin & 2016 & 2017 & 2018 \\
Laki-Laki & 124 & 196 & 218 \\
Perempuan & 181 & 260 & 285 \\
\hline Total & $\mathbf{3 0 5}$ & $\mathbf{4 5 6}$ & $\mathbf{5 0 3}$ \\
\hline
\end{tabular}

Berdasarkan Tabel 1. diketahui pasien perempuan yang paling banyak mendapatkan terapi antbiotik di Puskesmas Aur Duri Kota Jambi periode 2016-2018. Perempuan memiliki risiko lebih sering terinfeksi jika dibandingkan dengan laki-laki, dikarenakan perempuan
Kota Jambi Periode 2016-2018. Data yang digunakan adalah rekam medik dan buku register pasien rawat jalan yang mendapatkan terapi antibiotik sesuai dengan kriteria.

Variabel pada penelitian ini adalah ATC/DDD Dan DU 90\% berdasarkan Jenis Kelamin, Usia, Diagnosa Penyakit, Jenis Antibiotik yang digunakan, Nilai DDD/1000 Pasien/Tahun dan DU 90\%.

Data yang diperoleh akan dikumpulkan dan dijadikan data dasar untuj kemudian diolah dan dianalisa penggunaan antibiotiknya. Pengolahan data dilakukan dengan menggunakan sistem ATC dengan unit pengukuran DDD/1000 Pasien/Tahun.

Tabel 2. Karakteristik Berdasarkan Usia Pasien Tahun 2016-2018

\begin{tabular}{cccc}
\hline RENTANG USIA & $\mathbf{2 0 1 6}$ & $\mathbf{2 0 1 7}$ & $\mathbf{2 0 1 8}$ \\
\hline $18-25$ & 42 & 85 & 124 \\
$26-35$ & 84 & 125 & 150 \\
$36-45$ & 109 & 157 & 177 \\
$46-55$ & 55 & 70 & 38 \\
$56-65$ & 7 & 14 & 12 \\
$>65$ & 8 & 5 & 2 \\
\hline Total & $\mathbf{3 0 5}$ & $\mathbf{4 5 6}$ & $\mathbf{5 0 3}$ \\
\hline
\end{tabular}


Berdasarkan Tabel 2. di dapatkan pravalensi jumlah pasien dengan usia 36 tahun-45 tahun lebih banyak mendapatkan terapi antibiotik dibandingkan rentang usia yang lain.Dimana usia ini disebut juga usia yang aktif karena orang dari usia ini banyak yang melakukan kegiatan atau aktivitas berbagai macam diluar rumah dan mengkonsumsi banyak jenis makanan yang kurang sehat atau kurang bersih ${ }^{9}$, sedangkan semakin bertambahnya usia seseorang lebih rentan terkena penyakit infeksi karena mengalami kemunduran fisik dan penurunan

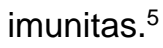

Tabel 3. Jumlah pasien berdasarkan diagnosa penyakit di di Puskesmas Aur Duri Kota Jambi periode

\begin{tabular}{lccc}
\multicolumn{1}{c}{ DIAGNOSA PENYAKIT } & $\mathbf{2 0 1 6}$ & $\mathbf{2 0 1 7}$ & $\mathbf{2 0 1 8}$ \\
\hline Abses & 15 & 9 & 9 \\
Arthritis & 1 & 0 & 0 \\
Dermatitis & 82 & 126 & 137 \\
Dispepsia & 3 & 15 & 18 \\
Febris & 17 & 47 & 44 \\
Genitourinari & 2 & 2 & 5 \\
Hipertensi & 5 & 3 & 3 \\
ISK & 4 & 20 & 11 \\
ISPA & 132 & 199 & 235 \\
Konjungtivitis & 12 & 7 & 13 \\
Luka Bakar & 0 & 2 & 0 \\
Mata & 7 & 9 & 10 \\
Migrain & 4 & 0 & 0 \\
Myalgia & 0 & 2 & 0 \\
Nekrosis Pulpa & 9 & 6 & 10 \\
Otitis & 8 & 1 & 1 \\
Rematik & 2 & 4 & 5 \\
Sinusitis & 0 & 4 & 2 \\
Sistitis & 2 & 0 & 0 \\
\hline & Total & $\mathbf{4 0 5}$ & $\mathbf{4 5 6}$ \\
\hline
\end{tabular}

Berdasarkan Tabel 3. Diketahui jumlah penyakit terbanyak di Puskesmas Aur Duri periode 2016-2018 yaitu ISPA (Infeksi Saluran Pernafasan Akut) Menurut data Dinas Kesehatan Provinsi Jambi tahun 2013-2015 nasofaringitis menempati posisi pertama penyakit terbesar di provinsi Jambi, yaitu sebanyak 110.305 pasien yang menderita penyakit tersebut. ${ }^{10}$ ISPA merupakan penyakit yang termasuk kedalam non pneumonia. ISPA salah satu penyakit infeksi yang bisa disebabkan oleh bakteri (genus Streptokokus,
Stafilokokus, Pnemokokus, Hemofilus, Bordetella dan Korinebakterium) maupun Virus (golongan Miksovirus, adenovirus, koronavirus, pikornavirus, Mikoplasma, dan Herpesvirus). Terapi pokok untuk infeksi saluran pernapasan akut adalah terapi dengan menggunakan antibiotik jika disebabkan oleh bakteri, jika disebabkan oleh virus maka tidak perlu penggunaan antibiotic. ${ }^{11}$ Penggunaan terapi antibiotik untuk ISPA non pneumonia tidak boleh melebihi dari angka yang telah ditetapkan yaitu $20 \% .^{12}$ 
Evaluasi Penggunaan Antibiotik Dengan Metode ATC/DDD dan DU 90\% di Puskesmas Aur Duri Kota Jambi Periode 2016-2018

Tabel 4. Karakteristik Berdasarkan Jenis Antibiotik yang digunakan Pasien Tahun 2016-2018

\begin{tabular}{ccccc}
\hline Jenis Antibiotik & Kode ATC & $\mathbf{2 0 1 6}$ & $\mathbf{2 0 1 7}$ & $\mathbf{2 0 1 8}$ \\
\hline Amoksisilin & J01CA04 & 198 & 318 & 326 \\
Siprofloksasin & J01CA02 & 61 & 73 & 84 \\
Tetrasiklin & J01AA07 & 23 & 33 & 52 \\
Eritromisin & J01FA01 & 23 & 32 & 41 \\
\hline
\end{tabular}

Dari hasil penelitian di Puskesmas Aur

Duri Kota Jambi pada periode 2016-2018 terdapat Empat jenis antibiotik yang digunakan di Puskesmas tersebut yaitu antibiotik Amoksisilin, siprofloksasin, tetrasiklin dan eritromisin. Berdasarkan formularium Puskesmas, penggunaan beberapa antibiotik seperti Amoksisilin, Siprofloksasin, Tetrasiklin dan Eritromisin dikarenakan Puskesmas merupakan pelayanan kesehatan tingkat dasar sehingga sebagian besar baik pada pasien Jamkesmas maupun BPJS diberikan obat yang bersifat generik dengan dosis sesuai kebutuhan. Jika penyakit tidak membaik maka akan diberikan antibiotik dengan dosis tambahan atau dirujuk ke Rumah Sakit sebagai pelayanan kesehatan tingkat lanjut.

Penggunaan terapi antibiotik yang paling banyak digunakan di Puskesmas Aur Duri periode 2016-2018 adalah amoksisilin.banyaknya penggunaan antibiotik amoksisilin kemungkinan dipengaruhi karena amoksisilin adalah antibiotik dengan aktivitas antibakteri spektrum luas, selain itu aktif pada bakteri gram positif (bakteri yang dinding selnya mempunyai lapisan peptidoglikan yang tebal) contohnya Bifidobacteriun, Lactobacillus, Staphilococcus, Clotridium, Actinomyces, Arachnia, Propionibacterium dan Peptostreptococcus. dan juga aktif pada bakteri gram negative (bakteri dinding selnya menyerap warna merah dan memiliki lapisan peptidoglikan yang tipis) contohnya aeruginosa, azotobacter, influenza, rhizobium leguminosarum, salmonella typhi, helicobacter pylori, neisseria gonorrchoeae, pseudomonas aeruginosa. ${ }^{13}$ Amoksisilin merupakan antibiotik yang banyak tersedia pada unit-unit pelayanan kesehatan masyarakat terutama puskesmas. ${ }^{14}$ Tingginya penggunaan amoksisilin di Puskesmas Aur Duri berdasarkan hasil diskusi dengan dokter, menurut dokter kecenderungan pemberian amoksisilin kepada pasien yaitu dengan alasan amoksisilin merupakan salah satu antibiotik yang bisa digunakan dengan baik untuk terapi empiris, mulai dari kasus infeksi ringan sampai dengan infeksi sedang.

Tabel 5. Hasil Analisa Kuantitatif Berdasarkan DDD/1000 Pasien/Tahun Dan DU 90\% Di Puskesmas Aur Duri Kota Jambi Periode 2016

\begin{tabular}{|c|c|c|c|c|}
\hline ANTIBIOTIK & KODE ATC & DDD/1000 & Persentase & $\%$ Kumulatif \\
\hline Amoksisilin & J01CA04 & 29,58 & $55,32 \% *$ & $55,32 \%$ \\
\hline Siprofloksasin & J01CA02 & 13,67 & $25.56 \%$ * & $80,88 \%$ \\
\hline Tetrasiklin & J01AA07 & 5,11 & $9,55 \% *$ & $90,43 \%$ \\
\hline Eritromisin & J01FA01 & 5,11 & $9,55 \%$ & $100 \%$ \\
\hline \multicolumn{2}{|c|}{ TOTAL } & 53.47 & $100 \%$ & $100 \%$ \\
\hline
\end{tabular}


Evaluasi Penggunaan Antibiotik Dengan Metode ATC/DDD dan DU 90\% di Puskesmas Aur Duri Kota Jambi Periode 2016-2018

Tabel 6. Hasil Analisa Kuantitatif Berdasarkan DDD/1000 Pasien/Tahun Dan DU 90\% Di Puskesmas Aur Duri Kota Jambi Periode 2017

\begin{tabular}{ccccc}
\hline ANTIBIOTIK & KODE ATC & DDD/1000 & Persentase & \%Kumulatif \\
\hline Amoksisilin & J01CA04 & 39,39 & $60,66 \%^{*}$ & $60,66 \%$ \\
Siprofloksasin & J01CA02 & 13,53 & $20,83 \%^{*}$ & $81.49 \%$ \\
Tetrasiklin & J01AA07 & 6,10 & $9,39 \%^{*}$ & $90,88 \%$ \\
Eritromisin & J01FA01 & 5,91 & $9,10 \%$ & $100 \%$ \\
\hline \multicolumn{2}{r}{ TOTAL } & $\mathbf{6 4 , 9 3}$ & $\mathbf{1 0 0} \%$ & $\mathbf{1 0 0 \%}$ \\
\hline
\end{tabular}

Tabel 7. Hasil Analisa Kuantitatif Berdasarkan DDD/1000 Pasien/Tahun Dan DU 90\% Di Puskesmas Aur Duri Kota Jambi Periode 2018

\begin{tabular}{|c|c|c|c|c|}
\hline ANTIBIOTIK & KODE ATC & DDD/1000 & Persentase & \%Kumulatif \\
\hline Amoksisilin & J01CA04 & 38,39 & $55,34 \% *$ & $55,34 \%$ \\
\hline Siprofloksasin & J01CA02 & 14,73 & $21,23 \% *$ & $76,57 \%$ \\
\hline Tetrasiklin & J01AA07 & 9,11 & $13,13 \%$ * & $89,7 \%$ \\
\hline Eritromisin & J01FA01 & 7,14 & $10,29 \%$ & $100 \%$ \\
\hline \multicolumn{2}{|c|}{ TOTAL } & 69,37 & $100 \%$ & $100 \%$ \\
\hline
\end{tabular}

Tabel 8. Hasil DU 90\% Periode 2016-2018

\begin{tabular}{ccccc}
\hline NO & Tahun & DDD/1000 & $\%$ & \%Kumulatif \\
\hline 1 & 2016 & 53.47 & $100 \%$ & $100 \%$ \\
2 & 2017 & 64,93 & $100 \%$ & $100 \%$ \\
3 & 2018 & 69,37 & $100 \%$ & $100 \%$ \\
\hline
\end{tabular}

Drug Utilization (DU 90\%) merupakan daftar obat yang masuk akumulasi 90\% penggunaan obat. ${ }^{15}$ Pada puskesmas Aur DuriKota Jambi antibiotik yang masuk dalam segmen DU $90 \%$ berdasarkan data periode 2016 adalah amoksisilin (55,32\%), siprofloksasin $(25,56 \%)$, tetrasiklin $(9,55 \%)$, dan eritromisin $(9,55 \%)$, sedangkan pada tahun 2017 adalah amoksisilin (60,66\%), siprofloksasin $(20,83 \%)$, dan tetrasiklin $(9,39 \%)$.dan eritromisin $(9,10 \%)$ pada tahun 2018 adalah amoksisilin (55,34\%), siprofloksasin $(21,23 \%)$, tetrasiklin $(13,13 \%)$, dan eritromisin $(9,10 \%)$

Pada Puskesmas berdasarkan data periode 2016-2018 diperoleh hasil bahwa antibiotik yang masuk ke dalam Segmen DU 90\% adalah Amoksisilin, Siprofloksasin dan Tetrasiklin. Antibiotik yang masuk ke dalam segmen DU $90 \%$ sangat penting dilakukan pemantauan penggunaannya untuk mencegah terjadinya resistensi. tenaga medis yang berwenang dalam pemberian obat, perlu mengontrol dengan baik penyerahan antibiotik terutama di Puskesmas.

Menurut $\mathrm{WHO}^{16}$, penggunaan antibiotik harus diminimalkan dalam penanganan infeksi. Semakin kecil nilai DDD maka semakin rendah kemungkinan terjadinya resistensi. Kuantitas penggunaan antibiotik yang kecil menujukkan dokter semakin selektif dalam memilih terapi untuk pasien, sehingga lebih mendekati prinsip penggunaan antibiotik yang bijak. ${ }^{17}$ Penggunaan antibiotik perlu dimonitoring karena diketahui bahwa penggunaan antibiotik yang berlebihan dapat meningkatkan terjadi resistensi dan hal inipun menjadi fokus secara nasional maupun global. $^{18}$ 
Penggunaan antibiotik di Indonesia, terutama di Kota Jambi perlu diberikan panduan dan pendiddikan tentang meresepkan antibiotik yang aman dan masuk akal. Tenaga medis yang berwenang perlu mengontrol pemberian antiiotik, jika penggunaan antibiotik tidak dikontrol akan terjadi resistensi antibiotik yang secara klinis membahayakan tubuh manusia.

Metode DU $90 \%$ merupakan metode yang bertujuan untuk membuat pengelompokan data dari penggunaan obat, sehingga dapat menilai kualitas dari penggunaan obat yang sering digunakan. Penilaian terhadap obat yang masuk kedalam segmen DU 90\% diperlukan untuk menekankan segmen obat tersebut dalam hal evaluasi, pengendalian penggunaan dan perencanaan pengadaan obat. ${ }^{19}$

Sebanyak 4 jenis antibiotik yang diberikan di Puskesmas Aur Duri tersebut tidak semua antibiotik masuk ke dalam segmen DU $90 \%$. Antibiotik yang masuk segmen DU $90 \%$ di Puskesmas Aur Duri kota Jambi periode 2016-2018 adalah amoksisilin, siprofloksasin, dan tetrasiklin. Sebuah Studi telah menunjukkan terdapat hubungan antara tingkat penggunaan antibiotik dengan kejadian resistensi. ${ }^{20}$

Menurut WHO ${ }^{16}$, bakteri yang mengalami resisten yaitu kondisi dimana bakteri menjadi kebal terhadap antibiotik. Sehingga antibiotik yang awalnya efektif untuk pengobatan infeksi menjadi tidak efektif lagi. Data WHO menunjukkan angka kematian akibat resistensi sampai tahun 2014 sekitar 700 ribu pertahun. Dengan cepatnya perkembangan dan penyebaran infeksi akibat bakteri resisten, pada tahun 2050 diperkirakan kematian tersebut lebih besar dibandingkan kematian akibat kanker. ${ }^{12}$

Antibiotik yang masuk ke dalam segmen DU $90 \%$ sangat penting dilakukan pemantauan penggunaannya untuk mencegah terjadinya resistensi. tenaga medis yang berwenang dalam pemberian obat, perlu mengontrol dengan baik penyerahan antibiotik terutama di Puskesmas. Masyarakat juga agar tidak menggunakan antibiotik tanpa diagnosa dokter terlebih dahulu. Diharapkan tenaga medis yang berwenang dalam pemberian obat dapat melakukan pemantauan dan evaluasi dari penggunaan antibiotik di fasilitas Kesehatan. ${ }^{12}$ Salah satu kebijakkan dalam menekan angka kejadian resistensi adalah pembatasan penggunaan antibiotik sehingga dapat dilakukan penggantian tren penggunaan antibiotik pada suatu periode tertentu. ${ }^{20}$

\section{KESIMPULAN}

Berdasarkan hasil penelitian Evaluasi Penggunaan Antibiotik dengan metode ATC/DDD dan DU 90\% Di Puskesmas Aur Duri Kota Jambi Periode 2016-2018 dapat ditarik kesimpulan yaitu dari hasil penelitian di dapatkan jumlah sampel penelitian di Puskesmas Aur Duri Kota Jambi periode 2016 sebanyak 305 Pasien, periode 2017 sebanyak 456 Pasien dan pada periode 2018 sebanyak 503 Pasien. Jumlah sampel di Puskesmas tersebut dikarenakan pertimbangan memenuhi kriteria. Dalam penelitian ini didapatkan data yaitu jenis kelamin, usia, diagnosa penyakit, jenis antibiotik yang digunakan, nilai DDD/1000 pasien/tahun dan segmen DU 90\%. Dari Empat jenis antibiotik, didapatkan nilai DDD tertinggi di Puskesmas Aur Duri periode 2016-2018 yaitu antibiotik amoksisilin. Antibiotik yang masuk ke dalam segmen DU 90\% di Puskesmas Aur Duri berdasarkan data periode 2016 -2018 adalah 
amoksisilin, siprofloksasin dan tetrasiklin. Data secara Kuantitatif dengan metode ATC/DDD yang terbanyak yaitu amoksisilin dengan angka tertinggi sebesar $39,39 \quad \mathrm{DDD} / 1000$ KPRJ/Tahun di puskesmas Aur Duri periode 2017 dan yang paling sedikit yaitu Eritromisin sebesar 5,11 DDD/1000 KPRJ/tahun di puskesmas Aur duri periode 2016.

\section{DAFTAR PUSTAKA}

1. Muslim, Zamharira. Antibiotic Prescription To Pediatric In Hospital Bengkulu, Indonesia: ATC / DDD Index. 2018; 10(5): 10-13.

2. Bätzing-Feigenbaum, Jörg et al. Outpatient Antibiotic Prescription." Deutsches Aerzteblatt Online. 2016; (113): 454-59.

3. Diany A, Arfania M. Analisis Penggunaan Antibiotika Dengan Metoda ATC/DDD Di Rumah Sakit Swasta Kab Karawang. Jurnal Sains dan IImu Farmasi. 2018; 3(2): 194-202.

4. Herawati, Fauna, Hartono ID, Pranajaya D. Antibiotic Use At Primary Healthcare Centers In Surabaya: A Surveillance Study." International Journal of Pharmacy and Pharmaceutical Sciences. 2017; 9(7): 7-10.

5. Pratama, Septa. Monitoring Penggunaan Antibiotik Di Bangsal Penyakit Dalam RSUD Kerinci. Riset informasi Kesehatan. 2019; 8(1): 57-62.

6. Endro, Nugroho A. Farmakologi Obat-Obat Penting Dalam Pembelajaran Ilmu Farmasi Dan Dunia Kesehatan. 1st ed. Yogyakarta: Pustaka Belajar, 2012.

7. Jumaa, Salma, and Karaman R. Antibiotics. Nova Science Publisher., 2015.

8. Ingersoll, Molly A. Sex Differences Shape the Response to Infectious Diseases. PLOS. 2017;13(12): 1-6.

9. Khairunnisa R, Rusli R, Hajrah. Profil Penggunaan Antibiotik Pada Pasien ISPA Di Beberapa Puskesmas Kota Samarinda. Seminar Nasional Kefarmasian. 2016; 4: 20-21.

10. Dinas kesehatan Provinsi Jambi. Profil Kesehatan Provinsi Jambi. Dinkes Provinsi
Jambi, 2016: 253. Retrieved from http://www.depkes.go.id/

PROFIL_KES_PROVINSI_2015/05_JAMB I_2015.pdf.

11. Kusumanata $M$, and Endrawati S. Pola Pengobatan Infeksi Saluran Pernafasan Akut (ISPA) Pasien Pediatrik Rawat Inap di RSUD Karanganyar Bulan November 2013- Maret 2014. IJMS -Indonesian Journal on Medical Science. 2013; 1(2): 4144.

12. Kemenkes. Kebijakan Peningkatan Penggunaan Obat Rasional (POR). Jakarta., 2017.

13. Vascarya C, Susanti R, Nurmainah. Evaluasi Penggunaan Antibiotika Berdasarkan Metode Prescribed Daily Dose (PDD) Pada Anak Di Rawat Inap Puskesmas Siantan Hilir Pontianak Periode Juli- Desember 2016. Jurnal Mahasiswa Farmasi Fakultas Kedokteran UNTAN. 2015; 3(1).

14. Chudlori B, Kuswadi M, Indrayudha P. Pola Kuman Dan Resistensinya Terhadap Antibiotika Dari Spesimen Pus Di RSUD Dr. Moewardi Tahun 2012. Pharmacon. 2012; 13(2): 70-76.

15. Alfian SD, Tarigan ES, Puspitasari IM, and Abdulah R. Profil Penggunaan Antituberkulosis Di Apotek di Kota Bandung Periode 2008 -2010. Jurnal Farmasi Klinik Indonesia. 2012; 147-53.

16. World Health Organization. Collaborating Centere for Drug Statistic Methodology ATC and DDD. 2015.

17. Mahmudah F, Sumiwi SA, Hartini S. Studi Penggunaan Antibiotik Berdasarkan ATC/DDD Di Bagian Bedah Digestif Disalah Satu Rumah Sakit di Bandung. Indonesian Journal of Clinical Pharmacy .2016; 5(4): 293-98

18. Pani S., et al. Monitoring Penggunaan Antibiotik Dengan Metode ATC / DDD Dan DU 90 \%: Studi Observasional Di Seluruh Puskesmas Kabupaten Gorontalo Utara. Jurnal Farmasi Klinik Indonesia. 2015; 4(4): 275-280.

19. Mahmudah F. Study of the Use of Antibiotics with ATC/DDD System and DU $90 \%$ in Digestive Surgery in Hospital in 
Evaluasi Penggunaan Antibiotik Dengan Metode ATC/DDD dan DU 90\% di Puskesmas Aur Duri Kota Jambi Periode 2016-2018

Bandung. Indonesian Journal of Clinical Pharmacy. 2016; 5(4): 293-98.

20. Hasrianna et al. Monitoring Penggunaan Antibiotik Dengan Metode ATC/DDD Dan
DU90 \% di RSUD Abepura Jayapura. Jurnal Farmasi Klinik Indonesia. 2015; 4(3): 218-225. 